\title{
Eractais da literatura: o diálogo epistolar entre Hilda Hilst e Caio Fernando Abreu
}

Andréa Jamilly Rodrigues Leitão ${ }^{1}$

\section{Notas sobre a produção epistolar: saudações iniciais}

AS CARTAS OUTRORA JÁ OCUPARAM UM ESPAÇO DE MAIOR ALCANCE E PRESTÍGIO NO DIA A DIA DOS INDIVÍDUOS, seja as de transação comercial, seja as de cunho íntimo. Sendo por natureza um gênero híbrido, a produção epistolar comporta diversas formas de manifestação, como o relato memorialístico, a dimensão documental ou cronística de um certo tempo-espaço ou, ainda, o traço autobiográfico ou confessional. Sob esse viés, tal modalidade permite um vaivém entre o elemento pessoal ou referencial fornecido pelo contexto e os expedientes pertinentes à linguagem literária. Esses deslizamentos entre os gêneros justificam-se, em última análise, pela utilização de uma matéria-prima comum: a palavra. Um exemplo basilar dentro do gênero são as prolíficas cartas de Madame de Sevigné (1626-1696) ou as célebres Cartas a um jovem poeta (1903-1908), de Rainer Maria Rilke, as quais põem para flertar a um só tempo os tecidos da vida, da história e da literatura. Quando trocadas por escritores, as missivas podem repercutir-se não raro nos veios de suas respectivas criações literárias. No cenário nacional, não se pode deixar de citar a expressiva correspondência entre Machado de Assis e Euclides da Cunha (1903-1906), Mário de Andrade e Manuel Bandeira (1922-1944), Clarice Lispector e Fernando Sabino (1946-1969) e, evidentemente, Hilda Hilst e Caio Fernando Abreu (1968-1990).

A missiva trata-se, a rigor, de uma escrita endereçada a um destinatário, mas que não deixa de se configurar como um exercício de elaboração pessoal. $\mathrm{O}$ ato de escrever uma carta implica necessariamente um dar-se a ver, uma projeção exterior daquele que dispõe do turno da enunciação. Nesse sentido, Michel Foucault aborda a correspondência sob o prisma do que designa de "escrita de si", tendo em vista que "ela constitui também uma certa maneira de cada um se manifestar a si próprio e aos outros. A carta faz o escritor 'presente' àquele a quem se dirige"². A narrativa epistolar desenha diálogos, aproximações, intimidades e relações mútuas entre vozes e corpos, que são presentificados durante a situação de comunicação.

O campo da crítica genética está atento ao exame da epistolografia ou de quaisquer documentos que estejam envolvidos direta ou indiretamente nos processos de criação de uma obra de arte. No importante ensaio "Qual genética para as correspondências?" (1999), José-Luis Diaz considera a carta enquanto "arquivo de literatura", visto que "testemunha a gênese de uma obra literária - da qual ela funciona como laboratório, ou simplesmente como caixa registradora - é o mais clássico, o mais conhecido, o mais seguro" ${ }^{3}$. Em outros termos, o gênero epistolar oferece uma oportunidade privilegiada de iluminar, em seus bastidores, a "gênese" artística em suas

\footnotetext{
${ }^{1}$ Doutoranda no Programa de Pós-Graduação em Literatura Brasileira da Universidade de São Paulo (USP). E-mail: andrealeitao@usp.br.

${ }^{2}$ FoucAult, Michel. “A escrita de si”. In: O que é um autor? Tradução de António Fernando Cascais e Edmundo Cordeiro. Lisboa: Vega, 1992, p. 149.

${ }^{3}$ DiAZ, José-Luis. “Qual genética para as correspondências?”. Tradução de Cláudio Hiro, com a colaboração de Maria Sílvia Ianni Barsalini. Manuscrítica, São Paulo, n. 15, 2007, p. 122-123.
} 
diferentes fases: desde o momento em que o livro está sendo gestado até a sua recepção pela crítica e as suas instâncias de legitimação.

Dentro do panorama da epistolografia e da crítica genética, Marcos Antonio de Moraes aponta "três fecundas perspectivas de estudo". A este trabalho importa tão somente a terceira arrolada pelo especialista, que diz respeito à interpretação da correspondência como um "arquivo da criação", isto é, o "espaço onde se encontram fixadas a gênese e as diversas etapas de elaboração de uma obra artística, desde o embrião do projeto até o debate sobre a recepção crítica favorecendo a sua eventual reelaboração. A carta, nesse sentido, ocupa o estatuto de crônica da obra de arte" ${ }^{4}$. Isso posto, a presente investigação partirá do trecho final da missiva de Caio Fernando Abreu, datada do dia 4 de março de 1970, para Hilda Hilst, que será aproveitado, em termos ficcionais, pela escritora na trama da narrativa “Axelrod (da proporção)", de Tu não te moves de ti, de 1980.

\title{
Hildinha e Caio E.: invocações de uma amizade
}

O volume extenso de cartas de Caio Fernando Abreu, organizado por Italo Moriconi e publicado pela editora Aeroplano em 2002, recobre um período longo de aproximadamente quatro décadas, de 1965 a 1995 . A prodigalidade de tal acervo deve-se ao fato de que, de acordo com a sua biógrafa Jeanne Callegari, o escritor gaúcho "era compulsivo em relação a escrever cartas: adorava conhecer pessoas novas, porque assim tinha mais gente com quem trocar correspondência. Caio escrevia três, quatro cartas por dia, às vezes, e eram cartas longas, de várias páginas, em que ele se expunha muito" ${ }^{5}$. Diante de tal práxis frenética e copiosa, é possível sustentar que Caio atende ao "gigantismo epistolar" ${ }^{6}$ de que fala um dos maiores missivistas do Brasil, o escritor Mário de Andrade. Além de traçar um significativo painel sociocultural das décadas de 1970, 1980 e 1990 no Brasil e de trazer a lume um recorte preciso dos anos de severa censura e de autoritarismo político do país, o organizador exprime a noção de que a correspondência do autor rio-sul-grandense se integra igualmente, como uma espécie de laboratório, ao seu conjunto literário:

\begin{abstract}
Na medida em que o trabalho de Caio era escrever, as cartas fazem parte do mesmo movimento produtivo de que brotam suas crônicas, suas ficções, suas peças teatrais, suas resenhas e matérias jornalísticas, assim como presumivelmente o seu diário, ainda não revelado ao público. Tudo produto de um mesmo processo de vida se fazendo na escrita, enunciação e enunciado condicionando-se mutuamente, escrita alimentando-se de vida, vida transcendida pelo simbólico, metáfora que universaliza. ${ }^{7}$
\end{abstract}

\footnotetext{
${ }^{4}$ MoraEs, Marcos Antonio de. "Epistolografia e crítica genética”. Ciência e Cultura, São Paulo, v. 59, n. 1, jan./mar. 2007, p. 30.

${ }^{5}$ CAllegari, Jeanne. Caio Fernando Abreu: inventário de um escritor irremediável. São Paulo: Seoman, 2008, p. 113-114.

${ }^{6}$ Em carta do dia 10 de novembro de 1924, Mário de Andrade escreve a Carlos Drummond de Andrade o seguinte: "Desculpe esta longuidão de carta. Eu sofro de gigantismo epistolar" (ANDRADE, Carlos Drummond de. A lição do amigo: cartas de Mário de Andrade a Carlos Drummond de Andrade anotadas pelo destinatário. Posfácio de André Botelho. São Paulo: Companhia das Letras, 2015, p. 22).

${ }^{7}$ MoriCONI, Italo. Introdução. In: ABREU, Caio Fernando. Caio Fernando Abreu: cartas. Organização de Italo Moriconi. Rio de Janeiro: Aeroplano, 2002, p. 15.
} 
Italo Moriconi opta por dispor as missivas em ordem cronológica na tentativa de recompor, por meio de registros cotidianos, o "romance fragmentado" da vida de Caio. No entanto, uma vez que a existência incita intermitentes "começos", o organizador do volume subverte tal cronologia na estruturação de duas seções que compõem respectivamente o livro: a primeira, intitulada "Todas as horas do fim (1980-1996)", e a segunda, “Começo: o escritor (1965-1979)". Em 2009, Paula Dip publica o livro Para sempre teu, Caio F. pela Record, no qual registra os laços de amizade compartilhados entre ela e o escritor gaúcho por via da sua correspondência. Anos mais tarde, em 2016, a jornalista lança, pela José Olympio, Numa hora assim escura, com 25 cartas inéditas e os seus respectivos fac-símiles de Caio e de Hilda Hilst, as quais foram compradas, em 2010, do poeta e colecionador baiano Antonio Nahud Júnior. Este frequentou a Casa do Sol, em Campinas, no início da década de 1990 e obteve a correspondência pelas mãos da própria poeta. Datadas entre os anos de 1971 e de 1990, as missivas revelam ao público a verdadeira paixão literária que unia os dois. A atriz e jornalista Ana Lúcia Vasconcelos foi a responsável por apresentá-los. Em 1968, Caio foi um dos primeiros residentes que conviveu com Hilda na Casa do Sol - espaço este construído por ela e que, em 1966, passou a ser a sua nova morada, onde passou a se dedicar integralmente à criação e que se configurou como um cenáculo para acolher os mais diferentes artistas. Lá ele escreveu boa parte do que culminará no seu volume de contos intitulado Inventário do irremediável (1970), ganhador do prêmio Fernando Chinaglia da União Brasileira de Escritores. Consoante Paula Dip,

A colaboração literária entre Caio e Hilda nasceu logo nos primeiros dias da Casa do Sol, com ele datilografando noite adentro textos que ela ditava e ele gravava. No dia seguinte faziam leituras em voz alta, corrigiam, editavam, consultavam espíritos, discutiam questões filosóficas, investiam em amores vãos, falavam mal de telenovelas e de inimigos em comum. Acima de tudo dividiam a sina de se atirar ferozmente às palavras. ${ }^{8}$

A sua estadia na Casa do Sol, apesar de ser um dos capítulos decisivos dentro da sua trajetória no universo das letras, não se prolonga por muito tempo, perdurando-se apenas pelos anos de 1968 e de 1969. Ainda que Caio vá residir em distintas geografias e mudar de endereço constantemente - obedecendo à sua natureza nômade -, a distância física é tão logo suprimida pela querência escritural da composição epistolar. Todavia, não é raro encontrar em algumas de suas cartas lamentações perante a causticante ausência de respostas da amiga - vale mencionar que, do total de cartas que formam o compilado organizado por Paula Dip, somente uma carta e um cartão postal são assinados por Hilda -, conforme é possível observar no seguinte trecho, do dia 23 de dezembro de 1971:

Você não imagina como eu gostaria de sentar ao seu lado e conversar longamente sobre todas essas coisas. Acho que você não sabe a importância que você tem para mim, e como me dói sentir a saudade que sinto e pensar, às vezes, que a minha vida está perdida e que nunca mais nos encontraremos. Soube pelo Moacir que esteve bastante doente, fiquei preocupado, você não mandou me dizer nada. Também, você nunca escreve, a não ser para responder às minhas

\footnotetext{
${ }^{8}$ DiP, Paula. Numa hora assim escura: a paixão literária de Caio Fernando Abreu e Hilda Hilst. Rio de Janeiro: José Olympio, 2016, p. 37.
} 
cartas, cada vez mais enfossantes, não? [...] por favor me escreva - estou muito sozinho, meus pais fizeram todo o possível para que eu me convencesse de que sou uma pessoa má e desprezível -, por favor não deixe de me escrever, eu ACREDITO demais em você, no que escreveu, no que você viveu, no que você foi e é - você é a única pessoa a quem eu recorreria numa hora assim escura, e é o que estou fazendo. ${ }^{9}$

Se as cartas da poeta não possuem, de fato, uma regularidade frequente, é possível preencher essa lacuna na interlocução ao revisitar a correspondência de Caio Fernando Abreu, haja vista que esta, ao vocalizar as réplicas de Hilda, encena os vestígios do diálogo entre eles. Convém sublinhar que, em meio à narração de acontecimentos da sua rotina, o autor de Morangos mofados (1982) reserva espaço não menos importante para estabelecer, de antemão, a recepção crítica da obra da amiga - a exemplo dos comentários que tece acerca do então intitulado volume Triângulo ${ }^{10}$ - e, também, para ficcionalizar. Neste último caso, inventa para si a persona literária de Caio F., o "primo intelectualizado da Christiane" ${ }^{\text {" }}$. Além dessa rubrica, o escritor também assina em missiva do dia 15 de novembro de 1969 como "Koio" ${ }^{2}$. Ou, em outros casos, como consta na carta do dia 29 de abril de 1969, Caio emprega criativamente o vocativo "querida Unicórnia"13 para se referir à amiga. Tais designações remetem-se às personagens Koyo e Unicórnio, as quais pertencem respectivamente às narrativas "Floema" e "O unicórnio", de Fluxo-floema (1970), de Hilda Hilst.

Em sua "Introdução", Italo Moriconi salienta que as missivas do escritor destinadas à poeta, mormente as escritas em meados da década de 1970, documentam o proêmio da sua voz ficcional. A amizade e a admiração entre eles perfazem sentimentos tão intensos a ponto de invadirem a seara literária. Exemplo disso é a dedicatória da narrativa "Lázaro", de Fluxo-floema, realizada especialmente para Caio. Em carta de 29 de dezembro de 1970, este a confidencia ter ficado muito "comovido" com o seu gesto:

Fiquei demais comovido com o livro, com a dedicatória, com o Lázaro para mim, com o meu nome no prefácio. Orgulhosíssimo. Que bom, Hildinha, que recompensador pensar que todas aquelas nossas tardes batendo máquina, aqueles papos infindáveis à noite, as dúvidas, a pesquisa - pensar que tudo isso ganhou forma concreta e comunicável aos outros. Você não imagina como tudo isso é importante para mim. Poucas horas atrás, no ônibus com um amigo, pensava em você, em Dante, na fazenda, em toda aquela força mental que a gente desprendeu e

\footnotetext{
${ }^{9}$ Ibidem, p. 73-75.

${ }^{10}$ Em meados dos anos 1960, Hilda Hilst escrevia o livro Triângulo a ser publicado somente com "Osmo”, "Lázaro” e "O unicórnio”. O projeto de tal tríptico narrativo foi abandonado devido a questões financeiras e editoriais. Os textos foram incorporados à obra Fluxo-floema, que, em 1970, foi lançada pela editora Perspectiva, com prefácio de Anatol Rosenfeld. Em carta do dia 29 de abril de 1969, Caio Fernando Abreu pontua a sua perplexidade em relação às narrativas da amiga: "Não conheço nada de tão novo na literatura brasileira como o teu Triângulo" (ABREU, 2002, p. 365).

${ }^{11}$ Em assinatura de carta enviada do "Rio sem sol", em 13 de junho de 1983, Caio Fernando Abreu faz referência à protagonista do romance autobiográfico best-seller, intitulado Eu, Christiane F., 13 anos drogada e prostituída, de 1978 (Ibidem, p. 122).

${ }^{12}$ Ibidem, p. 391.

${ }^{13}$ Ibidem, p. 363.
} 
me perguntava ao mesmo tempo 'pra quê?'. A resposta é o Fluxo-Floema, é você dizer que não me esqueceu. ${ }^{14}$

Toda a "força mental" e o empenho investidos nos bastidores da criação, a saber, tudo o que concerne à ordem da experiência vivida é passível de "ganhar forma concreta e comunicável”, transfigurando-se na matéria da própria literatura. As cartas confessam as fronteiras porosas existentes entre os domínios da existência e da ficção. No que tange ao escritor rio-sul-grandense, Marie-Hélène Passos sintetiza que "a sensação que se tem ao ler a correspondência de Caio F. é que ele está sempre em processo de criação, pois, mesmo na escritura com função comunicativa que tem uma carta, muitas vezes, surge a própria criação poética, o poema, ou o esquema de uma peça, ou a ideia de um conto, ou um esboço de personagem” ${ }^{15}$. Deste modo, a epistolografia, por preservar a memória do percurso redacional, pode ser concebida à luz de "um 'canteiro de obras' ou um 'ateliê', [que] busca descortinar a trama da invenção" ${ }^{16}$. A palavra escrita burilada no fazer artístico cumpre o seu propósito de não fazer "esquecer", de sorte que, perenizada em obra de arte, pode alcançar o que se precipita no porvir - os leitores pósteros ${ }^{17}$.

\section{Da carta à ficção: a operação de apropriação pela narrativa hilstiana}

A carta de Caio F., aqui selecionada para apreciação, integra o volume sistematizado por Italo Moriconi. Conforme o próprio organizador faz questão de assinalar, o conjunto completo da correspondência do amigo recebida pela escritora pode ser encontrado no Fundo Hilda Hilst. Este contém, preservado em seu acervo, correspondências, fotografias, desenhos, agendas, cadernos de anotações e de estudos, documentos manuscritos ou datiloscritos da sua lavra, os quais estão disponíveis para consulta no Centro de Documentação Cultural “Alexandre Eulalio” (CEDAE-IEL-Unicamp). A missiva é constituída, no total, por quatro páginas datilografas, com poucas rasuras. Aliás, o exercício de "bater máquina” era um dos quais Caio se dedicava com maior afinco no momento da escrita, ora dos seus textos literários, ora da sua correspondência para familiares e amigos. O que chama a atenção é a presença de dois postscriptum grafados a caneta nas margens, sugerindo que o escritor muito provavelmente refletia e revisitava com ponderação os seus próprios escritos. Segue abaixo o seu trecho final:

\footnotetext{
${ }^{14}$ Ibidem, p. 410.

${ }^{15}$ PAssos, Marie-Hélène. Caio Fernando Abreu - cartas redescobertas: da memória adormecida à leitura genética. Letras de Hoje, v. 45, n. 4, out./dez. 2010, p. 41.

${ }^{16}$ MORAES, op. cit., p. 30.

${ }^{17}$ Expressão empregada por Hilda Hilst em carta enviada no dia 21 de agosto de 1990 ao amigo escritor e artista plástico José Luís Mora Fuentes, que, assim como Caio, frequentou a Casa do Sol: "Sapo (será que devo te chamar de Mora Fuentes, já que pretendemos que os pósteros nos leiam?), isso de Sapo e Lacraia vai soar mal” (Polito, Ronald (org.). Cartas aos pósteros: Correspondência de Hilda Hilst e Mora Fuentes (1970-1990). São Paulo: E-Galáxia, 2018. E-book).
} 




Figura 1 - Última página da carta datilografada de Caio Fernando Abreu para Hilda Hilst (Fonte e reprodução: CEDAE-

IEL-Unicamp, Fundo Hilda Hilst, HH I. 2. 00066, pasta 3, fólio 04).

Em seu início, o escritor gaúcho divide com "Hildinha" a sua tristeza pelo falecimento da poeta Lupe Cotrim Garaude e exterioriza a sua preocupação com a saúde do seu pai e a fragilidade da sua própria. Ademais, ilustra a sua angústia com o contexto sociopolítico do país a partir de dois episódios pontuais: primeiro, a censura instaurada no país com base no decreto-lei no 1.077, de 26 de janeiro de 1970, o qual proíbe quaisquer publicações contrárias à moral e aos bons costumes; segundo, a perseguição de hippies e de todos aqueles que dispõem de comportamentos desviantes no tocante às convenções sociais. Do cenário nacional para o da sua realidade, o escritor não economiza palavras para questionar a aura de conservadorismo vigente em Porto Alegre, que "sempre foi uma cidade nazista, cheia de grupos de defesa familiar e coisas do gênero" ${ }^{\text {" }}$.

O contexto de produção, após o golpe militar de 1964, remonta ao avanço de uma mentalidade liberal, fincada em valores tais como a liberdade individual, a igualdade formal e a propriedade privada; ao mesmo tempo, à intensificação do combate ao socialismo. Em seu ensaio "Cultura e política, 1964-1969: alguns esquemas”, Roberto Schwarz constrói uma visão bastante abrangente a respeito da circulação cultural realizada no período e constata a seguinte situação: "Apesar da ditadura da direita há relativa hegemonia cultural da esquerda no paí" ${ }^{19}$. O crítico percebe esta espécie de "anomalia" como o "traço mais visível do panorama cultural brasileiro entre 64 e 69". ${ }^{20}$ Mesmo antes da instalação da ditadura, Schwarz verifica que a direita conservadora já

\footnotetext{
${ }^{18}$ ABREU, op. cit., p. 397.

${ }^{19}$ SCHWARZ, Roberto. Cultura e política, 1964-1969. In: O pai de família e outros estudos. São Paulo: Companhia das Letras, 2008, p. 71, grifos do autor.

${ }^{20}$ Ibidem, p. 71.
} 
"conseguira ativar politicamente os sentimentos arcaicos da pequena burguesia" 21 , com a valorização de princípios tradicionais, tais como a pátria, a família, a religião, o latifúndio e a propriedade privada. Um exemplo disso localiza-se em uma série de manifestações reacionárias, iniciadas em março de 1964, as quais receberam o nome de "Marcha da família, com Deus pela liberdade". Sob essa esfera ideológica, o governo empreendeu o enfrentamento a um suposto inimigo prestes a rebelar-se sob um levante subversivo ou, mais especificamente, promoveu a repressão violenta ao movimento operário e camponês.

Retomando as linhas argumentativas desenvolvidas por Roberto Schwarz, Heloísa Buarque de Hollanda caracteriza o momento cultural que antecede e culmina na ditadura militar nos seguintes termos:

a produção cultural, largamente controlada pela esquerda, estará nesse período pré e pós-64 marcada pelos temas do debate político. Seja ao nível da produção em traços populistas, seja em relação às vanguardas, os temas da modernização, da democratização, o nacionalismo e a 'fé no povo' estarão no centro das discussões, informando e delineando a necessidade de uma arte participante, forjando o mito do alcance revolucionário da palavra poética. ${ }^{22}$

Na virada dos anos 1960 para os 1970, houve uma mudança de foco nas preocupações de setores da juventude e da intelectualidade brasileira, em virtude de um quadro de profunda crise de valores. O surgimento dessa nova geração decorre da passagem pelo Tropicalismo e da difusão da contracultura no país, associando-se a uma postura de desconfiança quanto a ortodoxias de qualquer ordem. Nessa direção, assomam ao debate o uso catártico de tóxicos, a emancipação dos corpos, a psicanálise, o rock e os circuitos alternativos. Para compreender melhor este painel de contestação e de inclusão das minorias marginalizadas, a ensaísta desenha-o muito bem a partir do que denominou de "atitude pós-tropicalista":

a valorização da marginalidade urbana, a liberação erótica, a experiência das drogas, a festa, casam-se, de maneira pouco pacífica, com uma constante atenção em relação a certos referenciais do sistema e da cultura, como o rigor técnico, o domínio da técnica, a preocupação com a competência na realização das obras. A marginalidade é tomada não como saída alternativa, mas no sentido de ameaça ao sistema; ela é valorizada exatamente como opção de violência, em suas possibilidades de agressão e transgressão. A contestação é assumida conscientemente. $\mathrm{O}$ uso de tóxicos, a bissexualidade, o comportamento descolonizado são vividos e sentidos como gestos perigosos, ilegais e, portanto, assumidos como contestação de caráter político. $^{23}$

Diante desse clima de autoritarismo político, Caio Fernando Abreu posiciona-se ao lado do movimento de contracultura e da geração desbunde dos anos 1970. Ao mesmo tempo que denuncia, imputa-lhe uma atuação de oposição a todas as formas de coação e de cerceamento a manifestações de cunho crítico perpetradas pelo regime ditatorial militar; principalmente no período pós-68, a partir do recrudescimento do governo implementado

\footnotetext{
${ }^{21}$ Ibidem, p. 82.

${ }^{22}$ HollandA, Heloísa Buarque de. Impressões de viagem: CPC, vanguarda e desbunde: 1960/70. Rio de Janeiro: Aeroplano, 2004, p. 21.

${ }^{23}$ Ibidem, p. 77.
} 
pelo AI-5, com os seus exílios políticos, cassações de mandatos, prisões, torturas e mortes. Com o fito de dirimir o divórcio existente entre os literatos e os estratos populares, o tom enérgico de Caio apela aos seus pares a assumir o papel social de resistência: "Não seria esta a hora exata dos escritores se reunirem e tomarem uma posição rígida e irreversível?” ${ }^{24}$. Esta conjuntura de protesto e de reivindicação propicia a aparição de seres ditos marginais, provenientes das camadas urbanas desprivilegiadas e classificados, como: desempregados, bandidos, favelados e subversivos. No plano da ficção, há a ascensão de personagens que problematizam a temática do negro, do homossexual e mesmo dos representantes de fluxos migratórios. Por outro lado, o autor rio-sulgrandense exibe um testemunho vivo de sua época às voltas com uma atmosfera de impotência e de absoluto desalento entre os jovens; os quais, muitas vezes, encontram o seu escape seja na letargia do sono - no qual Caio se inclui -, seja rendendo-se às drogas e aos mais diferentes métodos de entorpecimento:

A minha maneira de fugir, tu sabes, é dormindo. Andei dormindo até quinze horas por dia, durante quase duas semanas. Nos contatos com que tenho com gente da minha geração, ou de outras, mas unidos pela mesma lucidez, percebo de maneira intensa a mesma sensação de abandono e de inutilidade. Sobretudo de impotência. O consumo de drogas como meio (ótimo) de alienação e como meio (falso) de libertação é uma coisa incrível, assustadora mesmo. A maconha rola em Porto Alegre, as 'picadas' também, agora descobriram mescalina em Sta. Catarina e uns conhecidos meus, pintores, estão fazendo tráfico e vendendo para toda a 'classe artística' de PA. E o mais assustador nessa estória de drogas é que são consumidas justamente pela parte mais esclarecida da população, pelos que poderiam fazer alguma coisa. Os outros, as camadas mais baixas, têm a televisão, as novelas, as revistinhas de amor. Eu tenho o sono, talvez a fuga mais saudável, se bem que igualmente desesperadora. ${ }^{25}$

Caminhando para o desfecho da carta, Caio F. retira-se de um registro mais circunstancial relacionado a acontecimentos do seu cotidiano e às suas impressões de leituras literárias para ceder espaço ao campo da ficcionalidade. Talvez a chave da fabulação the pareça uma possibilidade de fugir do seu "exílio" voluntário nas paragens no sul do país e de atender ao seu estado de "ser nômade", continuamente em trânsito e movência. Inclusive, chega a celebrar o espírito da amiga, recitando os primeiros versos do poema "Do amor contente e muito descontente", de Roteiro de silêncio (1959): "Iniciei mil vezes o diálogo. Não há jeito./ Tenho me fatigado tanto todos os dias/ Vestindo, despindo e arrastando amor/ Infância,/Sóis e sombras.” ${ }^{26}$ Sob esta perspectiva, o autor entretece uma narrativa, na qual se figura uma crítica ferrenha à "dura" realidade sofrida pelo "Povo Brasileiro", sob a ameaça da opressão e do seu lastro de violência estampados pelo "Fascismo":

Sei que vais te preocupar com esta carta, mas eu não poderia escrevê-la de outra maneira. Se essas coisas não são boas de serem lidas, não são também boas de serem escritas. A verdade é que tudo está muito duro para todos nós. E a verdade mais insuportável é que somos justamente nós os culpados: a situação não teria ficado assim se esse rebotalho humano oficialmente conhecido como 'povo brasileiro' não tivesse permitido, desde o início. Sabes qual

\footnotetext{
${ }^{24}$ ABREU, op. cit., p. 399.

${ }^{25}$ Ibidem, p. 401.

${ }^{26}$ HILST, Hilda. Da poesia. São Paulo: Companhia das Letras, 2017, p. 96.
} 
é a imagem que me vem à mente quando penso nisso tudo? É assim: o Fascismo, um sujeito enorme, peludão, gênero estivador, botando na bunda do Povo Brasileiro, um sujeitão magro, pálido, subdesenvolvido e preguiçoso como Macunaíma. No começo o Povo Brasileiro deixa, por preguiça, só um pouquinho não faz mal, por medo de levar porrada e, mesmo, no começo não dói muito. Mas acontece que o Fascismo tem um SENHOR pau, e não se contenta em botar um pouquinho, quer empurrar tudo. E vai empurrando cada vez mais. O Povo Brasileiro começa a se sentir incomodado, pensa vagamente em reclamar, mas conclui que, afinal, homossexualismo é uma coisa válida e se tantos suportam (pensa rapidamente no seu amigo Povo Espanhol, que virou bicha louca) ele pode também suportar. Aí, de repente, o Fascismo empurrou tanto que não é possível tirar mais. Ficou entalado. E goza trezentas e quarenta e cinco vezes seguidas enquanto o Povo Brasileiro morre de hemorragia anal. The end. ${ }^{27}$

Aqui, insinua-se Macunaíma ${ }^{28}$, a personagem protagonista do romance homônimo, de 1928, de Mário de Andrade. Ele representa o Povo Brasileiro, enquanto “sujeitão magro, pálido, subdesenvolvido e preguiçoso”. O Fascismo, o seu oponente, é personificado por um "sujeito enorme, peludão, gênero estivador". Ante a sua posição de subalternidade e o seu estado de inanição crônica, o Povo Brasileiro curva-se, sem oferecer nenhum tipo de objeção ou de obstáculo, perante as repetidas investidas do seu carrasco, cujo "SENHOR pau" introduz com toda a sua pungência na "brasilíssima fundura" - para empregar uma expressão hilstiana -, de sorte que provoca a sua morte por "hemorragia anal".

Caio F. engendra um antagonismo entre o Povo Brasileiro e o Fascismo, tendo como base a naturalização da brutalidade concretizada na invasão do primeiro pela gerência totalitária do segundo, que persegue a qualquer custo o estabelecimento do domínio total ${ }^{29}$; ou, sob a égide de uma ideologia patriarcal, a performatização da própria dinâmica de dominação e de submissão. No que concerne a este último aspecto, os efeitos nocivos de uma cultura machista residem justamente no fato de as práticas sexuais consideradas desviantes serem tachadas de abjetas ou de doentias. Logo, interessa perceber a problematização da violência presente na lógica de tais relações de poder e nos impasses enfrentados por uma "sexualidade sem paz". ${ }^{30}$ Pode-se considerar que o escritor rejeita a heteronormatividade como paradigma prescritivo para a conduta sexual. Esse modelo imperante de masculinidade acaba sendo introjetado e reproduzido pela sexualidade de orientação gay na performatividade de

\footnotetext{
${ }^{27}$ ABREU, op. cit., p. 401-402.

${ }^{28}$ Além de ser um dos livros mais representativos do modernismo brasileiro, Macunaíma tornou-se, na década de 1960, um longa-metragem, sob a direção de Joaquim Pedro de Andrade, com a atuação de Grande Otelo e de Paulo José no papel do protagonista. Em carta para Hilda, em 10 de novembro de 1969, Caio comenta a sua recepção sobre o filme dias após a sua estreia: "Fui ver Macunaíma, um filme excelente, talvez o melhor filme brasileiro" (Ibidem, p. 389).

${ }^{29}$ No que tange aos propósitos centrais dos regimes totalitários, Hannah Arendt esclarece que "a luta pelo domínio total de toda a população da terra, a eliminação de toda a realidade rival não totalitária, eis a tônica dos regimes totalitários; se não lutarem pelo domínio global como objetivo último, correm sério risco de perder todo o poder que porventura tenham conquistado" (ARENDT, Hannah. Origens do totalitarismo: antissemitismo, imperialismo e totalitarismo. Tradução de Roberto Raposo. São Paulo: Companhia das Letras, 2012, p. 531).

${ }^{30}$ Ao examinar os aspectos homoeróticos pertinentes à sua ficção, João Silvério Trevisan ressalta a "voz personalíssima de Caio Fernando Abreu, com seus contos cheios de rapazes sonhadores e abúlicos, em clima pós-desbunde, procurando amor na cidade grande ou arrastando consigo uma sexualidade sem paz - descoberta às vezes com surpresa na figura de um sargento sádico, às vezes com ansiedade no corpo latejante de um primo mais velho etc." (TREVISAN, João Silvério. Devassos no paraíso. Rio de Janeiro: Record, 2000, p. 265).
} 
papéis desiguais, estipulados em ativo e passivo. Nos termos da narrativa, de um lado, existe o detentor de todo o poderio, avivado pelo seu "SENHOR pau”; de outro, aquele que lhe resta apenas “suportar” a opugnação.

Não é nenhuma novidade que um dos procedimentos literários contumazes de Hilda Hilst se revela na apropriação textual não somente de excertos ou de formulações dos seus próprios livros para empregar em outros de sua autoria; assim como de pensamentos de filósofos ou de outros literatos, quando não estes acabam sendo assimilados, por pouco, como personagens de seus textos. A sua obra como um todo, cuja verve experimental desafia as fronteiras estanques entre os gêneros, espelha o caráter polimórfico do seu exercício como escritora, uma vez que, além de prosadora, foi também poeta, dramaturga e cronista.

Antes de tudo, é preciso inteirar-se do enredo de “Axelrod (da proporção)", que é a última das três narrativas que compõem a obra Tu não te moves de ti, de Hilda Hilst. Narra-se a existência do professor de história Axelrod Silva, de quarenta e dois anos, que viaja de trem para a aldeia onde nasceu e lá se encontra com Haiága, a sua tia. Quanto à composição do seu título, Edson Costa Duarte detém-se na explicação do nome do protagonista: "axel = axial, relativo ou pertencente a eixo, (fig.) fundamental, primordial; rod = roda; Silva = sobrenome comum a muitos brasileiros”31. Vale notabilizar que o protagonista já carrega em seu próprio nome a insígnia do popular. Além disso, não se pode deixar de mencionar que o livro em questão foi publicado em meio ao regime de opressão política pertinente à ditadura militar brasileira (1964-1985) e, ainda, reitera em imagens as atrocidades cometidas durante a Segunda Guerra Mundial (1939-1945). Embora possa parecer ao leitor desavisado que a produção literária de Hilda Hilst seja avessa às discussões de natureza política, é possível constatar, pelo contrário, que a sua obra está bastante afinada com a sua conjuntura atual e as "brasilidades revolucionárias” ${ }^{2}$. Em consequência disso, não é desinteressada a construção de uma personagem fundamentalmente imersa no corpo sociopolítico da história. Tal entrada se efetiva à medida que Axelrod se oferece em sacrifício para e pelo ser coletivo:

Vou entrando na História, endurecendo, vou morrendo explodindo em faíscas, a cavernosa vai me comendo, ímã gozozo, já não sou Axelrod Silva, sou nomes, fachadas, sou máscara, já não penso, pensam por mim, sou credo, sou catecismo, sou bandeira, sou acorde, sou principalmente Político, o peito teso empinado, tenho ideias mas já não sou Axelrod Silva, tudo o que quiserdes, menos eu, a História me chupa inteiro, a língua porejando sangue goza filhinho

sim dona História, vou indo, estou cheio de ideias, tenho dúvidas, tenho gozos rápidos e agudos, vou te apalpando agora, o povo me olha, o povo quer muito de mim, gosto do povo, devo ser o povo, devo ser um único e harmônico povo-ovo, devo morrer pelo povo,

\footnotetext{
${ }^{31}$ DuARTE, Edson Costa. “Os personagens de Hilda Hilst: Kadosh, Axelrod e Hillé”. Kakope, v. 12, n. 23, 2016, p. 112. Esta explicação corrobora a explanação da própria Hilda Hilst, na qual, em entrevista para Léo Gilson Ribeiro, já havia se debruçado sobre os termos que formam o nome da sua personagem: "O Axelrod Silva se chama assim por quê? Por causa de Axel, que vem de axial, rod, de roda, e Silva vem de brasilidade, o Brasil, essa sensibilidade nossa, não é?” (HILST, Hilda. Fico besta quando me entendem: entrevistas com Hilda Hilst. Organização de Cristiano Diniz. São Paulo: Globo, 2013, p. 65).

${ }^{32}$ No final da década de 60, a autora escreveu oito peças teatrais. O contexto manifesta uma notória significação política, uma vez que se reporta ao período sombrio e conturbado do golpe militar e o ataque à democracia, a ausência de liberdade de expressão e a supressão dos direitos humanos. Em 1974, publica o livro Júbilo, memória, noviciado da paixão. Especialmente pelos "Poemas aos homens do nosso tempo", os últimos do volume, nos quais existem um tom político-social bastante evidente. Em seus versos iniciais, eis o papel primordial que cabe aos poetas: "Repensamos a tarefa de pensar o mundo" (HILST, 2017, p. 286).
} 
adentrando nele, devo rugir e ser um só com o povo, Axelrod-povo, Axelrod-coesão, virulência, Axelrod-filho do povo, HISTÓRIA/POVO. ${ }^{33}$

Ao conjugar-se com a massa informe do povo, fundindo-se em "Axelrod-povo" e "Axelrod-coesão", o professor esfacela os contornos da sua subjetividade: "chutei minha comensurabilidade, meu limite, meu finito fibroso, minha putrescível cabeça, minha vermelha dura fixa cabeça" ${ }^{34}$. Imbuído pelo sentido de dever ou de missão no seu compromisso com o povo e a justiça vindoura, Axelrod buscará iluminar a sua Verdade, trilhando o caminho similar ao de Jesus Cristo. Com efeito, para que isso ocorra, o primeiro precisará percorrer o seu suplício que corresponderá ao calvário do segundo, conforme este lhe enuncia: "Axelrod Silva, também sentes o todo como eu? um todo entrelaçado de sangue e violência? também te sentes homem como eu?” ${ }^{35}$. Acompanhado por um moço, Axelrod empreende uma "subida" em direção ao topo de uma colina, que acaba se tornando para ele um rebaixado e "ridículo Gólgota", quer dizer, a designação dada ao calvário onde Jesus foi crucificado - o caminho da cruz $^{36}$. O trajeto prepara-o para uma via de destruição ${ }^{37}$, tal como foi o gesto sacrificial de Jesus Cristo, que se presta a ele como um modelo: "um ridículo Gólgota, sorrio, falta um, não deveriam ser três? Ele e os dois, e faltam cruzes, os dois viram-no subir lá do alto das cruzes? E faz falta a multidão, os lamentos, e a hora da subida não foi esta, subiu a que hora Jeshua? ao meio-dia?”38.

Paralelamente ao jogo no qual se forja a personificação absoluta e implacável da "dona História", o professor encarna a figura de "Axelrod-filho do povo" e reconhece o seu destino atrelado à identidade de ser brasileiro, o "Grande Saqueado". Ao comentar a produção literária dos anos 1980, Regina Zilberman delimita como traço marcante a emergência da voz do oprimido. A ficção orienta-se pela tentativa de expressão do elemento popular, que, em alguns casos, transparece em "personagens simbólicas que encarnem o homem do povo; este não é identificado a nenhuma classe social, mas corresponde via de regra ao indivíduo que, dentro da pirâmide social ficcionalmente representada, ocupa a posição inferior" ${ }^{39}$. Neste cenário, o texto de Hilda Hilst elege Axelrod como um representante do "homem do povo" a fim de expor o contexto de perversa exploração e alienação, bem como as mazelas sociais provenientes da situação de subdesenvolvimento dos países da América Latina. A escritora reelabora, por seu turno, o olhar crítico desenvolvido por Caio ao estabelecer o confronto direto entre o estereótipo da virilidade masculina, sob a máscara do "Macho Silva" - aquele que se autoafirma por praticar atividades, tais como fornicar as mulheres e "chutar a bola" durante uma partida de futebol entre amigos -, e a

\footnotetext{
${ }^{33}$ Idem, 2018a, p. 426.
}

${ }^{34}$ Ibidem, p. 427.

${ }^{35}$ Ibidem, p. 422.

${ }^{36}$ O termo "Gólgota" faz referência ao local onde Jesus foi crucificado. Segue a passagem do Evangelho Segundo São João (19, 16-18), na qual o significado de tal expressão é explicitado: “"Então Pilatos o entregou para ser crucificado. Então eles tomaram a Jesus. ${ }^{17} \mathrm{E}$ ele saiu, carregando a sua cruz, e chegou ao chamado 'Lugar da Caveira' - em hebraico chamado Gólgota $-{ }^{18}$ onde o crucificaram; e, com ele, dois outros: um de cada lado e Jesus no meio" (BÍBLIA. Português. A Bíblia de Jerusalém. São Paulo: Paulus, 1995, p. 2036).

${ }^{37}$ Para Marcel Mauss e Henri Hubert, o sacrifício é um "procedimento [que] consiste em estabelecer uma comunicação entre o mundo sagrado e o mundo profano por intermédio de uma vítima, isto é, de uma coisa destruída durante a cerimônia" (MAUSS, Marcel; Hubert, Henri. Sobre o sacrifício. Tradução de Paulo Neves. São Paulo: Cosac Naify, 2013, p. 105, grifos dos autores).

${ }^{38}$ HILST, 2018a, p. 428-429.

${ }^{39}$ ZILBERMAN, Regina. Brasil: cultura e literatura nos anos 80. Organon, v. 17, n. 17, 1991, p. 99. 
imagem corroída do "grande pobre macho saqueado", que, posicionado "de quatro", concede o seu "acósmico buraco" ao seu onipotente algoz:

cheiro como um homem, aprumo-me, sou um homem, tropeço, estou de bruços, de bruços pronto para ser usado, saqueado, ajustado à minha latinidade, esta sim, real, esta de bruços, as incontáveis infinitas cósmicas fornicações em toda a minha brasilidade, eu de bruços vilipendiado, mil duros no meu acósmico buraco, entregando tudo, meus ricos fundos de dentro, minha alma, ah muito conforme seo Silva, muitíssimo adequado tu de bruços, e no aparente arrotando grosso, chutando a bola, cantando, te chamam de bundeiro os ricos lá de fora seo Silva Brasileiro, seo Macho Silva, hôhôhôhô enquanto fornicas bundeiramente as tuas mulheres cantando chutando a bola, que pepinão seo Silva na tua rodela, tuas pobres junturas se rompendo, entregando teu ferro, teu sangue, tua cabeça, amoitado, às apalpadelas, meio cego cedendo, cedendo sempre, ah Grande Saqueado, grande pobre macho saqueado, de bruços, de joelhos, há quanto tempo cedendo e disfarçando, vítima verde amarela, amado macho inteiro de bruços flexionado, de quatro, multiplicado de vazios, de cais, de multiirracionais, boca de miséria, me exteriorizo grudado à minha História, ela me engolindo, eu engolido por todas as quimeras.

machucou-se

nem um pouco

Trêmulo me levantando, eu Axelrod me levantando porque o Grande Saqueado deixo ali de bruços, descola-te de mim, eu sozinho sou mínimo, alavancas do sonho, as impossíveis para te levantar, ideias palavras abstrações textos dialéticas, impossíveis alavancas de sonhos impossíveis, beijo-te as nádegas, brasilíssima fundura, teus gordos aparentes, beijo lívido tua escura saqueada rodela, te pranteio ${ }^{40}$.

Se Jesus, o redentor, é oferecido em sacrifício pela humanidade para a absolvição de seus pecados; o "Grande Saqueado" ${ }^{41}$ dispõe-se igualmente à morte como um mártir nacional, que, de "bruços vilipendiado", sacrifica-se em prol do povo brasileiro. O professor depara-se com a faceta determinista e pessimista do transcurso histórico, no qual a condição do brasileiro é a de ser sempre uma "vítima verde amarela" da especulação do grande capital sobre os seus recursos naturais e humanos. "Sozinho" e "mínimo", despoja-se diante de uma realidade tomada pelo esvaziamento dos sentidos e as “impossíveis alavancas de sonhos impossíveis”. Axel, todavia, não consegue desfazer-se da sua condição de homem, preso às engrenagens da sua historicidade. Ao alcançar finalmente o ápice de sua jornada mística, o professor sucumbe no seu afã de transcendência - também impossível -, que não

\footnotetext{
${ }^{40}$ HILST, 2018a, p. 429.

${ }^{41} \mathrm{Na}$ crônica "Sistema, forma e pepino", do dia 25 de janeiro de 1993, Hilda Hilst reforça a sua crítica, com aguçada ironia, à condição de "saqueado" que não apenas diz respeito ao povo brasileiro, mas que também recobre o cenário latinoamericano: "Digo mais: poetas e latino-americanos não existem. Existem, sim, para serem saqueados. Em qualquer forma de governo, presidencialismo, parlamentarismo ou (!?!) monarquismo, nós, brasileiros, latino-americanos, sempre seremos saqueados" (Idem. 123 crônicas: Cascos \& carícias e outros escritos. Prefácio Zélia Duncan; introdução Ana Chiara. Rio de Janeiro: Nova Fronteira, 2018b, p. 37). Convém destacar, ainda, que o texto realiza uma citação direta do livro Tu não te moves de ti. Tal imagética é retomada, mais uma vez, na crônica "Casa do prazer”, do dia 27 de setembro de 1993: “Triste é o país cujos habitantes são chamados lá fora de 'bundeiros' porque cultuam traseiros. Triste é o país que está sempre de quatro para o Primeiro Mundo e não se enxerga dobrado, saqueado, dando sempre o buraco” (Ibidem, p. 103).
} 
se consuma; perfazendo, em acrobacias circulares, a sua queda, o salto mortale: "vou me levantando inteiro abade, curvado vou me fazendo, tento chamar a velhice, fazer ares de, quero ser velhíssimo neste instante, e agachado correndo, num urro senil estaco. E numa cambalhota despenco aqui de cima, nos ares, morrendo, deste lado do abismo" ${ }^{42}$. Desse modo, em contraposição à ascese e à elevação espiritual de Cristo, Axel cumpre a sua travessia que o encaminha ao enigma abissal da vida e aceita, ao apelar para uma decrepitude corpórea com um "urro senil", o seu destino humano: a sua finitude como um ser condenado à morte.

Com o uso de imagens pujantes, os textos de Caio Fernando Abreu e de Hilda Hilst amplificam o fortalecimento nefasto do Estado totalitário e terrorista do século $\mathrm{XX}$ - a exemplo das experiências decorrentes do Nazismo e do Fascismo - e convocam a consciência de que, enquanto o ser humano permanecer lidando de modo destrutivo para com o outro e consigo próprio, todo o gozo do prazer, o clarão da liberdade e a pulsão de vida lhe serão furtados. No plano linguístico, o tom contundente inscreve-se na retomada de um registro coloquial do Modernismo de 1922 e em uma sintaxe do rebaixamento, ou melhor, do baixo corporal presente em expressões como: "SENHOR pau”, "mil duros", “acósmico buraco", "rodela", "pepinão". É digno de nota que a utilização enfática de letras maiúsculas é um expediente bastante frequente no conjunto literário hilstiano.

Sob esse prisma, a insinuação ao homoerotismo ${ }^{43}$ presente tanto na correspondência quanto na ficção pode apontar, por meio do seu caráter questionador e desestabilizador, para uma ruptura com a hegemonia do regime heterossexual e uma abertura para pensar diferentes possibilidades de se relacionar sexualmente. Ambos desvendam o autoritarismo e os seus procedimentos de imposição do poder, que se alastram não apenas pelo território sexual, mas também pelo político-cultural, na medida em que as tecnologias de disciplina e de controle institucionalizados pelo Estado e seus aparelhos recaem tanto sobre os corpos e os seus desejos quanto sobre a ordem ideológica dos discursos. Dada a relação intricada entre a exploração, o sexo e a carnalidade, Hilda Hilst chega inclusive a nomear o poder como uma "rameira" 4 .

Em consonância com os estudos de Michel Foucault, a produção em torno do sexo articula-se no sentido da criação de mecanismos encarregados da vigilância e da administração dos corpos, domesticando-os de acordo com os paradigmas sociais vigentes. Destarte, o dispositivo da sexualidade corresponde à "grande rede da superfície em que a estimulação dos corpos, a intensificação dos prazeres, a incitação ao discurso, a formação dos conhecimentos, o reforço dos controles e das resistências, encadeiam -se uns aos outros, segundo algumas grandes estratégias de saber e de poder" ${ }^{45}$. Além de caracterizar-se como uma forma de inconformismo e de contestação política, a prática homoerótica pode ser uma via de reivindicação de um

\footnotetext{
${ }^{42}$ Idem, 2018a, p. 430.

${ }^{43}$ Em concordância com Jurandir Freire Costa, optou-se pelo termo "homoerotismo" em detrimento de "homossexualidade" ou "homossexualismo" - este último, extremamente datado, foi o empregado na missiva de Caio -, uma vez que estas designações reiteram uma carga de preconceito e, ainda, um espectro patológico ligado ao desvio e à anormalidade (CosTA, Jurandir Freire. A inocência e o vício: ensaios sobre o homoerotismo. São Paulo: Relume Dumará, 1992).

${ }^{44} \mathrm{Na}$ crônica “Eu... hein!”, do dia 25 de junho de 1995, a escritora, além de associar o poder à figura da prostituta, isto é, daquela que troca favores sexuais por dinheiro, insiste na fórmula do coito anal para exemplificar a dinâmica de exploração e de sujeição: "Como digo eu: o poder é como uma rameira, ela diz to a fim e se abre inteira. Vamos abrrrirrr!!! E isso quer dizer: tomem o que quiser. E isso quer dizer: caiam de quatro, negada, assim como o gigante deitadão, rodela devastada. $\mathrm{E}$ não foi sempre assim?” (HILST, 2018b, p. 317).

${ }^{45}$ FouCAUlT, Michel. História da sexualidade I: a vontade de saber. Tradução de Maria Thereza da Costa Albuquerque e J. A. Guilhon Albuquerque. 13. ed. Rio de Janeiro: Edições Graal, 1999, p. 100.
} 
espaço livre e democrático para o exercício do pensamento e a fuga de qualquer sistema de subjugação a um padrão arbitrário de normalidade; visto que, por operar sob a chave da incerteza e da contradição ${ }^{46}$, abre-se para a matéria vertente da existência.

Não se pode perder de vista, ademais, a similitude entre os destinos de Axelrod Silva e de Macunaíma. Para isso, Hilda faz referência a uma matriz cristã; Caio, por sua vez, a uma matriz literária. No desfecho da rapsódia marioandradiana, o "herói de nossa gente" retorna à sua tapera no Uraricoera, onde experimenta a visão desencantada da sua querência e o seu silêncio cortante, que não deixa de refletir a sua própria degradação. Macunaíma soçobra ao ser conduzido pelo canto sedutor da Uiara. É quando, com o seu corpo mutilado, resolve abdicar da sua vida na terra e efetua a sua subida para o céu com a finalidade de virar o "brilho inútil das estrelas" ${ }^{47}$. No seu exílio cósmico, foi metamorfoseado na constelação da Ursa Maior. Se, no volume de Mário de Andrade, Macunaíma converge em si mesmo a entidade nacional dos brasileiros ou, ainda, a consciência de um hispano-americano; ao se traçar um paralelo - reservadas as devidas proporções de cada projeto literário -, “Axelrod-povo" ganha representatividade análoga na narrativa hilstiana. No entanto, a ascensão tanto de um quanto a do outro, que seguem à autoimolação final, não plenificam a sua reunião com o absoluto, tal como se figura na ressurreição de Cristo. Pelo contrário, os seus percursos são tingidos com a paleta do sangue da violência. O culto sacrificial de Macunaíma e o de Axelrod - os anti-heróis da nossa gente - atuam, em um viés eminentemente crítico, como uma alegoria da espoliação social, política, econômica e cultural do Brasil e da América Latina como um todo ou, no plano das idiossincrasias, dos despotismos ideológicos vergados, sobretudo, sobre as expressões do corpo e da sexualidade. Claudio Carvalho ressalta, em seu estudo comparativo acerca das obras de Hilda Hilst e de Caio Fernando Abreu, que os escritores, ao viabilizarem lugar de protagonismo a "heróis ex-cêntricos",

\footnotetext{
${ }^{46}$ No texto "Ser ou não-ser homossexual?", de Devassos no paraíso, João Silvério Trevisan caracteriza a homossexualidade antes como um estado marcado pela transitoriedade e a ambiguidade. Afinal, "homossexual é exatamente isso: duvidoso, instaurador de uma dúvida. Em outras palavras: algo que afirma uma incerteza, que abre espaço para a diferença e que se constitui em signo de contradição frente aos padrões de normalidade. Ou seja: trata-se do desejo enquanto devir e, portanto, como afirmação de uma identidade itinerante" (TREVISAN, op. cit., p. 43).

${ }^{47}$ ANDRADE, Mário de. Macunaíma: o herói sem nenhum caráter. Estabelecimento de texto de Telê Ancona Lopez e de Tatiana Longo Figueiredo. 2. ed. Rio de Janeiro: Nova Fronteira, 2013, p. 208. Tendo em vista que o final de Macunaíma resguarda um tom pessimista e melancólico, Telê Ancona Lopez pontua que "subir ao céu e virar estrela é caminho mitológico universal que soluciona estruturalmente o romance [...], mas que não resolve a problemática do herói incaracterístico; não o faz 'achar a verdade"' (LOPEZ, Telê Porto Ancona. Macunaíma: a margem e o texto. São Paulo: Hucitec, 1974, p. 82). José Antônio Pasta Júnior, por sua vez, compreende o movimento de subida do herói não como uma solução, mas apenas como uma reafirmação das suas contradições, uma vez que a sua fixação como constelação constitui antes uma "síntese negativa". Assim, "o brilho da estrela macunaímica é, antes de tudo, a fulguração de um malogro" (PASTA JÚNIOR, José Antônio. Tristes estrelas da ursa - Macunaíma. In: AVANCINI, José Augusto; SiLVA, Márcia Ivana de Lima e (Org.). Mário de Andrade. Porto Alegre: Unidade Editorial Porto Alegre/SMC, 1993, p. 28). A passagem do mesmo para o outro se dá, nos termos do crítico, por meio de uma "formação supressiva", na qual o sujeito se forma aniquilando a si mesmo, isto é, pressupõe um autodilaceramento; logo, tal regime se consuma à luz de um rito sacrificial. Neste sentido, conclui o articulista que Macunaíma, "herói brasileiro, ele foi ainda e não a última - chamado a realizar o impossível - fazer com que o movimento seja a imobilidade, o mesmo, o outro, e o ser, o não-ser. Ele o fez - como de rigor - pela autoimolação sacrificial, conforme o cruento rito nacional da formação supressiva" (Ibidem, p. 32).
} 
dão destaque em seus textos para os discursos e personagens que se se encontram 'fora do centro' hegemônico da cultura ocidental. Nas margens e nas fronteiras do mundo abstrato e ideal inventado pela racionalidade iluminista é que eles vão encontrar seus personagens e seu espaço de atuação. Vão buscar o ponto de vista do diferente, do louco, do velho, da criança, dos animais, do fanático atormentado pela divindade, dos exilados, dos viajantes, dos obcecados pela dúvida, dos abandonados pelo amor, dos solitários, dos suicidas, dos outsiders, dos aidéticos, enfim, dos marginalizados dos mais variados matizes... Seus personagens que trazem a dor e a consciência da diferença. [...] Os heróis ex-cêntricos presentes nas obras de Caio Fernando Abreu e Hilda Hilst demonstram que seres humanos que não se enquadram nos parâmetros rígidos da normalidade socialmente aceita no Ocidente. ${ }^{48}$

Para além disso, a imagem do buraco ou a do próprio sexo aludem à busca de um centro sobre o qual repousa uma verdade essencial: a verdade do corpo. O mergulho abismal nas entranhas do "acósmico buraco", a saber, nas funduras do ser humano jamais contempla apenas a si mesmo; contudo, de forma espiralar, amplificase em direção a outrem ou, em última instância, até chegar à ausência total das bordas individuais. Hilda e Caio despertam a potência recôndita presente no infinito interior de cada um, cuja abertura vigora em um terreno de impermanência e reverbera-se, em fluxo contínuo, como um canal de comunicação entre o dentro e o fora, o centro e a margem, o excesso e o interdito, o eu e o outro.

\section{À título de conclusão: despedidas}

As ressonâncias entre as esferas intercambiáveis da epistolografia e da ficção são, de fato, concretas. À guisa do espírito antropofágico investido na construção da miscelânea de vozes, de ritmos e de tessituras que costuram a rapsódia de Mário de Andrade, Hilda incorpora antropofagicamente ${ }^{49}$ a breve narração de Caio, reinventandoa criativamente para ressurgir dez anos mais tarde como uma imagem potente em Tu não te moves de ti. A carta apreciada aqui não se encontra a serviço do debate acerca da criação de uma obra de arte em específico, mas antes como um caminho aberto de trânsitos e de confluências propício para germinar uma obra a qual ainda

${ }^{48}$ Carvalho, Luiz Claudio da Costa. Pensando a margem: um diálogo com Hilda Hilst e Caio Fernando Abreu. 2003. 490 f. Tese (Doutorado em Letras). Faculdade de Letras, Universidade Federal do Rio de Janeiro, Rio de Janeiro, 2003, p. 485486.

${ }^{49}$ No Manifesto Antropófago, de Oswald de Andrade, publicado em 1928 - mesmo ano de publicação de Macunaíma: o herói sem nenhum caráter -, o escritor paulista explana as diretrizes desse novo movimento estético-filosófico, retomando como seu procedimento, por excelência, a cerimônia guerreira praticada pelos antepassados. Grosso modo, o ritual antropofágico realiza-se mediante o ato simbólico, no qual os canibais tupis devoram os seus inimigos, sob a imolação cruenta dos seus corpos, a fim de absorver as suas qualidades mais genuínas e alcançar a sua emancipação. No campo da criação artística, a antropofagia põe em jogo os mecanismos de reinvenção, inscritos sobre a dinâmica que ao mesmo tempo que cria, também destrói ou ressignifica. Para maiores aproximações entre as obras de Hilda Hilst e de Oswald de Andrade, recomenda-se a leitura do artigo de Nilze Maria de Azeredo Reguera, intitulado "De Oswald de Andrade a Hilda Hilst: o lúdico na literatura brasileira do último século" (2015), no qual a autora aborda o aspecto lúdico da prosa hilstiana, herança de Oswald de Andrade, passando também por Guimarães Rosa e Clarice Lispector; e da dissertação de Vania Pereira Gumiero, sob o título de Todos se engolem: uma leitura antropofágica de Cartas de um sedutor, de Hilda Hilst (2018), na qual a pesquisadora detém-se na antropofagia enquanto procedimento literário e, além disso, como possibilidade de atingir o outro e se deixar ser transformado por ele. 
habita o horizonte do porvir ou, para lembrar o belo título de Maurice Blanchot, do livro por vir. A originalidade contida na operação literária realizada pela poeta reside no próprio movimento de apossar-se proficuamente da imagem tecida pelo amigo. Dito de outra forma, o colóquio íntimo entre Hildinha e Caio F. pode ser uma oportuna ocasião para animar ou mesmo servir de mote para o ato criativo, o qual se inicia, decerto, muito antes do instante da publicação final. Ainda mais quando se trata de autores que experimentaram, com excelência, os mais variados espaços escriturais, como: a prosa, a dramaturgia, a crônica e, naturalmente, a correspondência. Tal ocorrência comprova, por fim, o fato de que, para grandes escritores, absolutamente tudo é suscetível de tornar-se literatura.

Hilda Hilst e Caio Fernando Abreu cultivam, cada um a seu modo, a valorização da carnalidade e do seu viés de erotização, sob uma dicção libertária, transgressora e irreverente, nem que para isso se cumprir seja necessário desafiar os órgãos de censura de um época submetida a um estado de exceção e entranhar-se em questões no mínimo espinhosas, tais como: a emergência do homoerotismo, as incongruências do projeto de modernização no plano econômico-político do Brasil e a desconstrução de um ideário ufanista em torno de uma entidade nacional - tema tão caro ao livro Macunaíma. Sendo assim, são escritores que se deslocam entre margens e centros, voltando os seus olhares para os interstícios do tempo-espaço da história do país. Procuram denunciar as mazelas sociais suportadas, em forma de sacrifício ou de expiação, por novos atores sociais, isto é, por personagens que representam com autenticamente o povo brasileiro. Afinal, como vida e ficção deflagramse enquanto vetores indissociáveis, Hilda e Caio constituem-se, além de literatos, como seres unidos pela paixão à verdade do humano e da própria palavra. Publicado em O Estado de São Paulo, em 9 de dezembro de 1995, poucos meses antes da morte de Caio, Hilda dedica-lhe em sua homenagem o texto "Ele é um escritor transparente”, coroando na dimensão do verbo - não poderia ser de outra maneira - a inteireza de uma amizade:

Mas Caio que chegou ao meu sítio aos 19 anos de idade era um menino que escrevia muito, estudava muito, trabalhava com enorme dedicação. Caio se transformou em um escritor que tem um tipo de transparência de que eu gosto muito. É muito difícil o escritor falar sobre a própria verdade. Se um escritor tem uma verdade, ele deve ser absolutamente claro, não deve usar máscaras, não deve falsificar.

O Caio é assim, um escritor que diz tudo o que sente e está sempre buscando a verdade. Eu gosto de toda a obra do Caio e principalmente da disciplina e do esforço que ele faz para se dizer inteiro. Ele é um escritor que sempre jogou limpo, sempre apostou tudo no que escreve.

O Caio empenha a vida, a morte, a doença, tudo o que tem em sua literatura. A tentativa do escritor é sempre essa: dizer a sua pequena verdade para o outro. ${ }^{50}$

\section{Referências bibliográficas}

\footnotetext{
${ }^{50}$ Hilst, Hilda. Ele é um escritor transparente. O Estado de S. Paulo, São Paulo, 9 de dezembro de 1995. O fragmento encontra-se também disponível no livro de Paula Dip (op.cit., p. 146).
} 
ABreU, Caio Fernando. Caio Fernando Abreu: cartas. Organização de Italo Moriconi. Rio de Janeiro: Aeroplano, 2002.

ANDRADE, Mário de. Macunaíma: o herói sem nenhum caráter. Estabelecimento de texto de Telê Ancona Lopez e de Tatiana Longo Figueiredo. 2. ed. Rio de Janeiro: Nova Fronteira, 2013.

ANDRADE, Carlos Drummond de. A lição do amigo: cartas de Mário de Andrade a Carlos Drummond de Andrade anotadas pelo destinatário. Posfácio de André Botelho. São Paulo: Companhia das Letras, 2015.

ARENDT, Hannah. Origens do totalitarismo: antissemitismo, imperialismo e totalitarismo. Tradução de Roberto Raposo. São Paulo: Companhia das Letras, 2012.

BíBLIA. Português. A Bíblia de Jerusalém. São Paulo: Paulus, 1995.

CALLEGARI, Jeanne. Caio Fernando Abreu: inventário de um escritor irremediável. São Paulo: Seoman, 2008.

Carvalho, Luiz Claudio da Costa. Pensando a margem: um diálogo com Hilda Hilst e Caio Fernando Abreu. 2003. 490 f. Tese (Doutorado em Letras). Faculdade de Letras, Universidade Federal do Rio de Janeiro, Rio de Janeiro, 2003.

CostA, Jurandir Freire. A inocência e o vício: ensaios sobre o homoerotismo. São Paulo: Relume Dumará, 1992.

DIAZ, José-Luis. Qual genética para as correspondências? Tradução de Cláudio Hiro, com a colaboração de Maria Sílvia Ianni Barsalini. Manuscrítica, São Paulo, n. 15, p. 119-162, 2007.

DIP, Paula. Numa hora assim escura: a paixão literária de Caio Fernando Abreu e Hilda Hilst. Rio de Janeiro: José Olympio, 2016.

DuARTE, Edson Costa. “Os personagens de Hilda Hilst: Kadosh, Axelrod e Hillé”. Kaliope, v. 12, n. 23, p. 106-122, 2016.

FouCAULT, Michel. "A escrita de si", in: O que é um autor? Tradução de António Fernando Cascais e Edmundo Cordeiro. Lisboa: Vega, 1992.

História da sexualidade I: a vontade de saber. Tradução de Maria Thereza da Costa Albuquerque e J. A. Guilhon Albuquerque. 13. ed. Rio de Janeiro: Edições Graal, 1999.

GUMIERO, Vania. Todos se engolem: uma leitura antropofágica de Cartas de um sedutor, de Hilda Hilst. 2018. 237

f. Dissertação (Mestrado em Literatura Brasileira). Faculdade de Filosofia, Letras e Ciências Humanas, Departamento de Letras Clássicas e Vernáculas, Universidade de São Paulo, São Paulo, 2018.

HILST, Hilda. Fico besta quando me entendem: entrevistas com Hilda Hilst. Organização de Cristiano Diniz. São Paulo: Globo, 2013.

Da poesia. São Paulo: Companhia das Letras, 2017.

. Da prosa. São Paulo: Companhia das Letras, 2018a. 2 v.

132 crônicas: Cascos \& carícias e outros escritos. Prefácio de Zélia Duncan. Introdução de Ana Chiara. Rio de Janeiro: Nova Fronteira, 2018b.

HollandA, Heloísa Buarque de. Impressões de viagem: CPC, vanguarda e desbunde: 1960/70. Rio de Janeiro: Aeroplano, 2004.

LOPEZ, Telê Porto Ancona. Macunaíma: a margem e o texto. São Paulo: Hucitec, 1974.

MAUSS, Marcel; HubERT, Henri. Sobre o sacrificio. Tradução de Paulo Neves. São Paulo: Cosac Naify, 2013.

Moraes, Marcos Antonio de. Epistolografia e crítica genética. Ciência e Cultura, São Paulo, v. 59, n. 1, p. 30-32, jan./mar. 2007. 
MoriCONI, Italo. "Introdução", in: ABREU, Caio Fernando. Caio Fernando Abreu: cartas. Organização de Italo Moriconi. Rio de Janeiro: Aeroplano, 2002. p. 9-21.

PASSOS, Marie-Hélène. "Caio Fernando Abreu - cartas redescobertas: da memória adormecida à leitura genética”. Letras de Hoje, v. 45, n. 4, p. 37-42, out./dez. 2010.

PASTA JÚNIOR, José Antônio. Tristes estrelas da ursa - Macunaíma. In: AVANCINI, José Augusto; SilVA, Márcia Ivana de Lima e (Org.). Mário de Andrade. Porto Alegre: Unidade Editorial Porto Alegre/SMC, 1993, p. 27-32.

Polito, Ronald (org.). Cartas aos pósteros: Correspondência de Hilda Hilst e Mora Fuentes (1970-1990). São Paulo: E-Galáxia, 2018. E-book.

Reguera, Nilze Maria de Azeredo. "De Oswald de Andrade a Hilda Hilst: o lúdico na literatura brasileira do último século", in: ; Busato, Susanna (Orgs.). Em torno de Hilda Hilst. São Paulo: UNESP, 2015. p. 49-73.

SCHWARZ, Roberto. Cultura e política, 1964-1969. In: O pai de família e outros estudos. São Paulo: Companhia das Letras, 2008.

TREVISAN, João Silvério. Devassos no paraíso. Rio de Janeiro: Record, 2000.

ZILBERMAN, Regina. Brasil: cultura e literatura nos anos 80. Organon, v. 17, n. 17, p. 93-104, 1991. 